\title{
Uji Aktivitas Antibakteri Ekstrak Etanol Rumput Laut Cokelat (Sargassum cristaefolium) terhadap Staphylococcus epidermidis
}

\author{
Zanira Faisal Harharah a, 1 , Dewi Suryania, ${ }^{2}$ Anggit Listyacahyani Sunarwidhi b, ${ }^{\star}$ \\ aProgram Studi Farmasi, Fakultas Kedokteran, Universitas Mataram, Mataram, \\ bakultas Kedokteran, Universitas Mataram, Mataram, \\ ${ }^{1}$ zanirafaisal@gmail.com; ${ }^{3}$ dewi.suryani@unram.ac.id; ${ }^{2}$ anggit.sunarwidhi@unram.ac.id* \\ *korespondensi penulis
}

\begin{tabular}{l} 
INFO ARTIKEL \\
\hline Diterima : \\
25-07-202I \\
Disetujui : \\
02-08-202I
\end{tabular}

\section{Kata kunci:}

Staphylococcus

epidermidis;

Sargassum

cristaefolium;

Aktivitas Antibakteri;

Ekstrak etanol 96\%;

Zona hambat

\section{ABSTRAK}

Staphylococcus epidermidis diketahui menyebabkan infeksi kulit oportunistik termasuk menyebabkan acne vulgaris. Pemilihan bahan alam rumput laut cokelat Sargassum cristaefolium diharapkan dapat digunakan sebagai alternatif baru terhadap tingginya angka resistensi bakteri akibat antibiotik. Tujuan penelitian ini adalah menentukan aktivitas antibakteri ekstrak etanol S.cristaefolium terhadap S.epidermidis. S.cristaefolium dikumpulkan dari pantai Batu Layar Lombok dan dimaserasi dengan etanol 96\%. Penelitian ini kemudian mencakup pemberian konsentrasi ekstrak etanol S.cristaefolium (60\%, 80\% dan 100\%) dan kontrol positif doksisiklin. Aktivitas antibakteri dari ekstrak diamati dengan metode difusi sumuran agar. Data yang diperoleh dianalisis statistik menggunakan uji parametrik One Way ANOVA. Hasil skrining fitokimia menunjukkan bahwa ekstrak etanol S.cristaefolium mengandung alkaloid, tanin, flavonoid, saponin, dan steroid serta memiliki daya hambat antibakteri pada konsentrasi 100\% dengan diameter hambat $9.46 \pm 1.60$ termasuk katagori sedang, konsentrasi $80 \%$ dan $60 \%$ memiliki daya hambat lemah dengan diameter $2.63 \pm 0.74$ dan $1.96 \pm 0.7 \mathrm{I}$. Bila dibandingkan kontrol positif, daya hambat ekstrak etanol S.cristaefolium memiliki hasil yang lebih rendah. Berdasarkan uji statistik One Way ANOVA, hasil aktivitas antibakteri ekstrak etanol S.cristaefolium berbeda signifikan dengan kontrol negative yang terlihat dari nilai $\mathrm{p}<0.05$.

Key word:
Staphylococcus
epidermidis;
Sargassum
cristaefolium;
Antibacterial activity;
$96 \%$ ethanol extract;
Zone of inhibition

\section{ABSTRACT}

Staphylococcus epidermidis is known to cause opportunistic skin infections including acne. The selection of natural material such as brown seaweed Sargassum cristaefolium is expected to be used as a new alternative to high number of bacterial resistance due to antibiotics. The purpose of this study was to determine the antibacterial activity of the ethanolic extract of S.cristaefolium against S.epidermidis. S.cristaefolium collected from Batu Layar coast Lombok and macerated with $96 \%$ ethanol. This research included the difference of any concentrations $(60 \%, 80 \%$ and $100 \%)$ and doxycycline as positive control. The Antibacterial activity of the extract would be observed by agar well diffusion method. The data was then analyzed statistically using the One Way ANOVA parametric test. The results of phytochemical screening showed the ethanolic extract of S.cristaefolium contained alkaloid, tannin, flavonoid, saponin, and steroid. The antibacterial test showed that at the concentration of I00\% S.cristaefolium had 9.46 \pm 1.60 of inhibition zone diameter and it was classified in to medium category. At the concentrations of $80 \%$ and $60 \%$ S.cristaefolium were classified in to weak category. The diameters of the inhibition zone were $2.63 \pm 0.74$ and $1.96 \pm 0.7 \mathrm{I}$. The research showed doxycycline as positive control has better result than any concentrations ethanol extract of S.cristaefolium. Based on the One Way ANOVA statistical test, the results of the antibacterial activity of S.cristaefolium ethanol extract were significantly different compared to the negative control, as seen from the $\mathrm{p}$ value $<0.05$.

This is an open access article under the CC-BY-SA license. 


\section{Pendahuluan}

Acne vulgaris merupakan penyakit kulit yang sering terjadi pada permukaan kulit yaitu pada daerah wajah, leher, dada, dan punggung (Sawarkar et al., 2010). Acne vulgaris dapat disebabkan oleh aktivitas kelenjar minyak yang berlebihan dan diperburuk oleh adanya infeksi bakteri, salah satnya adalah infeksi bakteri Staphylococcus epidermidis (Kursia et al., 2016) Staphylococcus epidermidis termasuk ke dalam bakteri gram positif anaerob yang dapat menyebabkan inflamasi pada kulit (Chomnawang et al., 2007). Menurut catatan studi Dermatologi Kosmetika Indonesia, pada tahun 2006, 60\% penduduk Indonesia menderita Acne vulgaris. Jumlah ini terus meningkat seperti yang ditunjukkan pada tahun 2007, 80\% penduduk Indonesia menderita Acne vulgaris dan 90\% penduduk menderita penyakit ini pada tahun 2009.

Berdasarkan (Wibawa \& Winaya, 2019), 71,2\% kejadian Acne vulgaris terjadi pada wanita, sedangkan sekitar $28,8 \%$ terjadi pada pria. Hal ini disebabkan karena pada wanita terdapat faktor pencetus seperti perubahan atau rendahnya hormon estrogen dan progesteron sebelum menstruasi dan juga adanya dampak penggunaan kosmetik (Hartono et al., 202I). Faktor lain yang dapat menjadi penyebab timbulnya Acne vulgaris antara lain faktor genetik, endokrin, psikis, musim, stress, makanan, dan bahan kimia lain (Latifah et al., 2015).

Acne vulgaris dapat menyebabkan masalah kesehatan seperti bekas luka berupa jaringan parut permanen pada wajah individu. Selain menimbulkan masalah kesehatan, acne vulgaris juga dapat mengganggu psikologis individu hingga dapat menyebabkan depresi. Menurut penelitian (Freire \& Filho, 20I5), ditunjukkan bahwa dari 317 responden yang memiliki masalah acne vulgaris, sekitar 48,6\% diantaranya merasa stres, $22 \%$ memiliki rasa takut bertemu seseorang untuk pertama kali, 19,4\% merasa takut untuk berfoto dan 8,5\% takut untuk bertemu dengan teman. Hal inilah yang memicu diperlukannya agen pengobatan acne.

Pemberian agen terapi antibiotik seperti klindamisin, tetrasiklin, doksisiklin dan eritromisin merupakan agen pilihan untuk pengobatan Acne vulgaris (Guay, 2007). Namun penggunaan suatu antibiotik yang berlebihan, dapat menyebabkan meningkatnya resiko resistensi dan timbulnya masalah efek samping terhadap suatu antibiotik. Berdasarkan hasil penelitian (Bernadette et al., 2019), terdapat beberapa antibiotik yang sudah mengalami resistensi terhadap bakteri Staphylococcus epidermidis yaitu golongan tetrasiklin, klindamisin dan eritromisin yaitu berturut-turut sebesar 32,6\%, 52,2\% dan 65,2\%. Selain itu masalah efek samping yang ditimbulkan untuk penggunaan tetrasiklin pada wanita hamil dapat menyebabkan penurunan pertumbuhan tulang dan perubahan warna gigi permanen pada anak (Garrett \& Margolis, 20I2).

Sargassum cristaefolium (S. cristaefolium) adalah alga cokelat yang dapat ditemukan di daerah perairan tropis, subtropis dan daerah bermusim dingin. Alga ini tumbuh di perairan pada kedalaman 0.5-I0 meter yang terdapat arus dan ombak (Triastrinurmiatiningsih et al., 20II). Jumlah Sargassum cristaefolium yang berlimpah selama ini hanya dimanfaatkan sebagai pakan benih ikan dan udang untuk pertumbuhan oleh masyarakat (Annisa et al., 2018). Penggunaan Sargassum cristaefolium dalam bidang farmakologi telah dimanfaatkan sebagai pelembab pada kulit (Manggau et al., 2017). Ekstrak Sargassum cristaefolium juga memiliki aktifitas antibakteri seperti yang telah diuji secara in vitro pada bakteri Escherischia coli dan Salmonella thyposa (Kartikaningsih et al., 2019).

Penelitian mengenai aktivitas antibakteri dari Sargassum cristaefolium masih terbatas, khususnya dalam pengobatan acne vulgaris. Penelitian ini bertujuan untuk menentukan aktivitas antibakteri ekstrak etanol Sargassum cristaefolium terhadap Staphylococcus epidermidis. Berdasarkan studi mengenai potensi Sargassum cristaefolium sebagai antibakteri yang cukup tinggi, maka diperlukan studi lebih lanjut mengenai hal tersebut. Penelitian ini diharapkan dapat menambah wawasan terkait potensi Sargassum cristaefolium dalam mengatasi permasalahan acne vulgaris.

\section{Metode}

\section{Alat dan Bahan}

Alat yang digunakan dalam penelitian ini adalah alat gelas, alumunium foil, batang pengaduk, bejana maserasi, blender, blue tip, pembakar Bunsen, cawan petri, gunting, hot plate $\left(\right.$ Labnet $\left.^{\mathbb{R}}\right)$, inkubator $\left(\right.$ Labnet $\left.^{\circledR}\right)$, jarum ose, kertas saring, mikropipet, mistar, autoclave (Tomy SX$\left.500^{\circledR}\right)$, spreader, tabung reaksi, timbangan analitik $\left(\right.$ Ohauss $^{\mathbb{E}}$ ), vaccum rotary evaporator $\left(\right.$ Heidolph $\left.^{\circledR}\right)$, vorteks.

Bahan yang digunakan dalam penelitian adalah alkohol $70 \%$ v/v, aquades, $\mathrm{BaCl}_{2}$ I\%,Doksisiklin, DMSO I0\% v/v, etanol 
96\%v/v $\quad\left(\right.$ Merck $\left.^{\circledR}\right), \quad \mathrm{H}_{2} \mathrm{SO}_{4} \quad \mathrm{I} \%, \quad$ isolat Staphylococcus epidermidis ATCC I2228, kapas, kertas saring, larutan $\mathrm{NaCl} \mathrm{0,9 \%} \mathrm{b/v,}$ nutrien agar (NA) $\left(\mathrm{Merck}^{\circledR}\right)$, rumput laut cokelat (Sargassum cristaefolium), tissue.

\section{Jalannya Penelitian}

a. Pengambilan dan Determinasi Tanaman

Sampel yang digunakan pada penelitian ini adalah rumput laut cokelat (Sargassum cristaefolium) yang diperoleh dari daerah pesisir pantai Batu Layar, Lombok Barat. dengan kriteria rumput laut cokelat yang segar serta pada wilayah 8०3I'9”S II603'49"E. Sampel telah dilakukan determinasi di Laboratorium Ekologi dan Biosistematika Tumbuhan, Fakultas Matematika dan Ilmu Pengetahuan Alam, Universitas Mataram untuk mengetahui kebenaran sampel yang digunakan dalam penelitian.

b. Pembuatan Simplisia Rumput Laut Cokelat

Sampel rumput laut cokelat (Sargassum cristaefolium) diambil sebanyak $3 \mathrm{~kg}$. Sortasi basah dilakukan dengan memisahkan bagian rumput laut dari kotoran yang menempel menggunakan air laut. Sampel dikeringkan hingga terbentuk butiran garam halus pada permukaan talus. Pengeringan dilakukan dengan metode kering-angin. Sampel kering diserbukkan dengan blender.

c. Pembuatan Ekstrak Rumput Laut Cokelat

Serbuk rumput laut cokelat ditimbang sebanyak 400 gram, kemudian dimasukkan dalam bejana maserasi dengan menambahkan $1600 \mathrm{~mL}$ pelarut etanol $96 \% \mathrm{v} / \mathrm{v}$ sampai serbuk simplisia terendam. Maserasi dilakukan selama Ix24 jam sambil sesekali dilakukan pengadukan. Dilakukan remaserasi dengan pelarut etanol 96\% v/v yang baru. Maserat dipekatkan dengan vaccum rotary evaporator $100 \mathrm{rpm}$, pada suhu $40^{\circ} \mathrm{C}$ hingga diperoleh ekstrak kental (Fitri \& Widiyawati, 2017).

d. Skrining Fitokimia

Skrining fitokimia dilakukan untuk metabolit alkaloid, tanin, flavonoid, saponin, dan triterpenoid/steroid. Adapun uji dari masing-masing metabolit dijelaskan pada prosedur berikut:

\section{(I) Uji Alkaloid}

Ekstrak Sargassum cristaefolium diambil sebanyak 0,05 mg kemudian dilarutkan dengan 5 tetes HCl. Uji dilakukan dengan menggunakan tiga pereaksi yaitu Dragendorff, Mayer dan
Wagner. Hasil uji dinyatakan positif jika terbentuk endapan putih (pereaksi Mayer), endapan cokelat (pereaksi Wagner) dan endapan jingga (pereaksi Dragendorff) (Minarti et al., 2019).

\section{(2) Uji Tanin}

Pada uji tanin dilakukan dengan 2 metode yang berbeda, yaitu dengan metode $\mathrm{FeCl}_{3}$ dan garam gelatin.

Ekstrak S. cristaefolium sebanyak 0,05 mg ditambahkan etanol sampai sampel terendam semuanya, kemudian ditambahkan 2-3 tetes larutan $\mathrm{FeCl}_{3}$ 5\%. Hasil positif ditandai dengan terbentuknya warna hitam kebiruan atau hijau (Kartikaningsih et al., 2019).

Sebanyak I mL ekstrak Sargassum cristaefolium ditambahkan 5 tetes $\mathrm{NaCl} \mathrm{IO} \%$, dilakukan pengadukan dengan mengoyanggoyangkan tabung reaksi. Kemudian ditambahkan larutan gelatin I \% beberapa tetes. Hasil positif ditandai dengan terbentuknya endapan putih (Trisia et al., 20I8).

\section{(3) Uji Flavonoid}

$2 \mathrm{~mL}$ ekstrak Sargassum cristaefolium ditambahkan I mL 2N NaOH. Terbentuknya warna kuning menunjukkan ekstrak positif mengandung flavonoid (Kartikaningsih et al., 2019).

\section{(4) Uji Saponin}

Ekstrak $S$. cristaefolium sebanyak 0,05 mg dimasukkan ke dalam tabung reaksi yang berisi air panas $5 \mathrm{~mL}$ kemudian didinginkan dan dikocok kuat selama IO detik. Selanjutnya ekstrak ditambahkan I-2 tetes HCl 2N. Hasil positif ditandai dengan terbentuknya buih yang stabil setinggi I-IO cm (Simaremare, 20I4).

\section{(5) Uji Triterpenoid/Steroid}

Ekstrak $S$. cristaefolium dilarutkan dalam $2 \mathrm{~mL}$ kloroform dalam tabung reaksi, kemudian ditambahkan 10 tetes anhidrida asetat dan 3 tetes asam sulfat pekat. Uji dinyatakan positif triterpenoid ditunjukkan adanya perubahan warna merah jingga samapi ungu dan warna biru - hijau untuk menandakan positif steroid (Kartikaningsih et al., 2019).

e. Pembuatan nutrient agar (NA) stok

Nutrient Agar stok dibuat dengan mengambil $20 \mathrm{~g}$ nutrient agar (NA) dan dilarutkan dalam I L aquades menggunakan 
Erlenmeyer. Media dihomogenkan dengan batang pengaduk diatas hotplate sampai mendidih. Media disterilkan dengan otoklaf selama I5 menit dengan suhu $121^{\circ} \mathrm{C}$ (Desrizal et al., 2020).

Media NA untuk peremajaan dibuat dengan mengambil $5 \mathrm{~mL}$ NA dari stok dan dituangkan kedalam tabung reaksi steril dan ditutup dengan kapas steril Media disterilkan dengan otoklaf dan ditunggu media memadat pada kemiringan \pm $30^{\circ}$ (Kumesan et al., 2013) Media bakteri uji dibuat dengan memanaskan media NA stok diatas hotplate, kemudian diambil sebanyak $20 \mathrm{~mL}$ dan dituangkan ke dalam cawan petri steril (Kumesan et al., 2013)

f. Pembuatan larutan standar Mc Farland

Larutan standar Mc Farland dibuat dengan menambahkan larutan $\mathrm{BaCl}_{2} \mathrm{I} \%$ sebanyak $0.05 \mathrm{~mL}$ kedalm tabung reaksi yang telah berisi larutan $\mathrm{H}_{2} \mathrm{SO}_{4} \mathrm{I} \%$ sebanyak $9.95 \mathrm{~mL}$, kemudian dilakukan pencampuran menggunakan vortex sampai tercampur sempurna ( Rosmania \& Yanti, 2020).

g. Pembuatan larutan perlakuan

Konsentrasi ekstrak yang diujikan dibuat dengan melarutkan ekstrak etanol rumput laut cokelat kedalam DMSO I0\% sesuai dengan konsentrasi yang diujikan yaitu 60\%,80\% dan $100 \%$.

h. Persiapan sampel uji bakteri

Peremajaan bakteri uji dilakukan dengan mengambil I ose isolat Staphylococcus epidermidis ATCC I2228, lalu digoreskan pada tabung miring dan dilakukan inkubasi selama 24 jam dengan suhu $37^{\circ} \mathrm{C}$. Suspensi bakteri uji dibuat dengan mengambil I ose bakteri yang telah diremajakan dan dimasukkan dalam tabung reaksi yang berisi $10 \mathrm{~mL}$ larutan $\mathrm{NaCl}$ 0.9\%. Selanjutnya dihomogenkan dengan vortex dan dibandingkan tigkat kekeruhan dengan standar Mc Farland 0.5 (Kumesan et al., 2013)

i. Uji aktivitas ekstrak etanol Sargassum cristaefolium

Pengujian aktivitas antibakteri ini dilakukan untuk mengetahui potensi antibakteri dari ekstrak etanol rumput laut cokelat yang dilakukan dengan metode difusi sumuran. Uji ini diawali dengan penyebaran suspense bakteri diatas media NA (base layer agar) yang telah memadat di atas cawan petri selanjutnya dituangkan media NA sebagai seed layer agar, kemudian dibiarkan memadat. Media yang telah memadat dibuatkan sumuran dengan diameter $8 \mathrm{~mm}$. setiap sumuran ditambahkan konsentrasi ekstrak sebanyak $100 \mu \mathrm{l}$ dan dilakukan inkubasi selama 24 jam dengan suhu $37^{\circ} \mathrm{C}$. Selanjutnya dilakukan pengamatan dan pengukuran zona bening yang terbentuk disekitar sumuran. kemudian dimaskkan kedalam rumus berikut untuk menghitung nilai rata-rata zona hambat. Dengan rumus (Winastri et al., 2020)

$$
L=\frac{(D 1-D 2)+(D 3-D 2)}{(2)}
$$

Keterangan;

L: luas zona hambat

DI: Diameter zona hambat horizontal

D2: Diameter zona hambat vertikal

D3: Diameter sumuran

\section{Hasil dan Pembahasan}

Sampel yang digunakan dalam penelitian ini telah dilakukan identifikasi di Laboratorium Biologi Lanjut Ruang Ekologi dan Biosistematika Tumbuhan, Fakultas Matematika dan Ilmu Pengetahuan, Universitas Mataram. Hasil identifikasi menunjukkan bahwa sampel tersebut adalah rumput laut cokelat (Sargassum cristaefolium C. Agardh).

Sebanyak $3 \mathrm{~kg}$ sampel rumput laut cokelat segar diambil di daerah pantai Batu Layar, Lombok Barat. sampel rumput laut segar dibersihkan dari kotoran yang menempel dan dikeringkan dengan metode kering anginkan. Hasil pengeringan diperoleh simplisia kering sejumlah $540 \mathrm{~g}$ dengan rendemen berat kering sebanyak I8\%. Simplisia Sargassum cristaefolium diilustrasikan pada Gambar I.

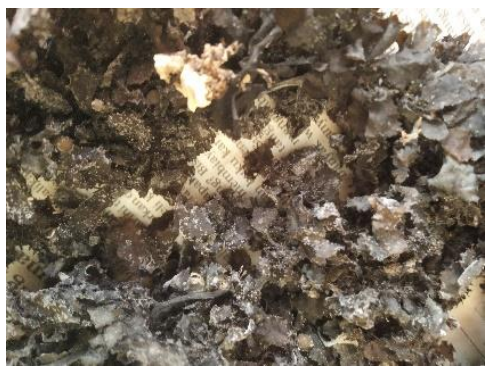

Gambar I. Simplisia Sargassum cristaefolium

Ekstraksi rumput laut cokelat dalam penelitian ini menggunakan metode maserasi. Sebanyak 400 g serbuk Sargassum cristaefolium direndam dalam etanol $96 \% \mathrm{v} / \mathrm{v}$ dengan 
perbandingan I:4. Maserasi dilakukan selama 24 jam dan dilakukan remaserasi sebanyak 2 kali dengan pelarut etanol yang baru. Hasil ekstraksi diperoleh ekstrak kental yang berwarna hijau kehitaman sebanyak 4I.II5 g dengan rendemen ekstrak kenal sebanyak 10,278\%.

Pengujian fitokimia dalam penelitian ini bersifat kualitatif, yaitu dengan melihat adanya endapan atau perubahan warna yang terbentuk setelah penambahan beberapa pereaksi untuk golongan alkaloid, saponin, flavonoid, tanin, steroid dan triterpenoid. Hasil skrining fitokimia ekstrak etanol Sargassum cristaefolium disajikan dalam Tabel I.

Tabel I. Hasil Skrining Fitokimia Sargassum cristaefolium

\begin{tabular}{|c|c|c|c|}
\hline Senya wa & Pereaksi & Hasil & Kesimpulan \\
\hline \multirow{3}{*}{ Alkaloid } & Mayer & $\begin{array}{c}\text { Terbentuk } \\
\text { endapan putih }\end{array}$ & + \\
\hline & Dragendroff & $\begin{array}{c}\text { Tidak terbentuk } \\
\text { endapan }\end{array}$ & - \\
\hline & Wagner & $\begin{array}{c}\text { Terbentuk } \\
\text { endapan cokelat }\end{array}$ & + \\
\hline Sanonin & Aquades $+\mathrm{HCl} 2 \mathrm{~N}$ & $\begin{array}{c}\text { Terbentul busa } \\
\text { setinggi I cm }\end{array}$ & + \\
\hline Flavonoid & $\mathrm{NaOH} 2 \mathrm{~N}$ & $\begin{array}{c}\text { Terbentuk warna } \\
\text { kuning }\end{array}$ & + \\
\hline \multirow{2}{*}{ Tanin } & $\mathrm{FeCl}_{5} 5 \%$ & $\begin{array}{c}\text { Terbentuk warna } \\
\text { hijau tua }\end{array}$ & + \\
\hline & Garam gelatin & $\begin{array}{c}\text { Terbentuk } \\
\text { endapan putilh }\end{array}$ & + \\
\hline Steroid & $\begin{array}{l}\text { Kloroform+ } \\
\text { H.SO +asam asetat } \\
\text { anhidrat }\end{array}$ & $\begin{array}{c}\text { Terbentuk wama } \\
\text { hijau kebiruan }\end{array}$ & + \\
\hline Triternenoid & $\begin{array}{l}\text { Kloroform+ } \\
\text { HSO +asam asetat } \\
\text { anhidrat }\end{array}$ & $\begin{array}{l}\text { Tidal terbentuk } \\
\text { warna kemerahan }\end{array}$ & - \\
\hline
\end{tabular}

Keterangan: $(+)$ positif: mengandung golongan senyawa; (-) negatif: tidak mengandung golongan senyawa.

Berdasarkan tabel I senyawa alkaloid, tanin, saponin, flavonoid, dan steroid terkandung dalam ekstrak etanol Sargassum cristaefolium. Hasil ini berbeda dengan penelitian sebelumnya yang dilakukan oleh (Kartikaningsih et al., 2019). Dalam penelitian tersebut, hasil skrining fitokimia menunjukkan hasil positif pada uji triterpenoid dan menunjukkan hasil negatif dalam pengujian senyawa saponin baik dalam sampel segar, kering maupun di dalam bubuk kering. Hal ini dapat dikarenakan adanya perbedaan bentuk sampel uji yang digunakan dalam pengujian skrining fitokimia, Selain itu menurut peneliatian (Made et al., 2019), adanya perbedaan geografis dan faktor lingkungan juga dapat menjadi alasan perbedaan hasil senyawa yang diperoleh.

Hasil pengujian ekstrak etanol Sargassum cristaefolium terhadap senyawa alkaloid menunjukkan hasil positif. Hal ini sesuai dengan penelitian (Syafriana et al., 202I), bahwa suatu sampel dapat dikatakan positif mengandung alkaloid jika setidaknya dua tes kualitatif yang dilakukan menunjukkan hasil positif dengan terbentuk endapan berwarna. Dalam penelitian ini pengujian Wagner dan Mayer menunjukkan hasil positif dengan terbentuknya endapan putih pada pereaksi Mayer dan endapan cokelat pada pereaksi Wagner.

Pada uji saponin, hasil positif ditandai dengan terbentuknya busa yang stabil setinggi II0 $\mathrm{cm}$ bahkan setelah penambahan $\mathrm{HCl} 2 \mathrm{~N}$ (Kartikaningsih et al., 2019). Dalam percobaan yang dilakukanmenunjukkan hasil positif dengan terbentunya busa stabil setinggi $\mathrm{I} \mathrm{cm}$ bahkan setelah penambahan $\mathrm{HCl} 2 \mathrm{~N}$. $\mathrm{Hal}$ ini dikarenakan senyawa saponin memiliki gugus hidrofilik dan hidrofobik yang akan berikatan dengan air dan udara sehingga dapat membentuk busa (Simaremare, 2014).

Pengujian flavonoid dalam penelitian ini menunjukkan hasil positif dengan adanya perubahan warna menjadi kuning. Hal ini sesuai dengan penelitian (Kusnadi \& Devi, 2017), bahwa senyawa Kristin yang merupakan turunan flavon akan mengalami penguraian oleh basa menjadi molekul seperti asetofenon yang berwarna kuning setelah penambahan $\mathrm{NaOH}$ I0\%.

Uji tanin dalam penelitian ini dilakukan dengan 2 metode, yaitu dengan $\mathrm{FeCl}_{3} 5 \%$ dan garam gelatin. Hasil positif pada penambahan $\mathrm{FeCl}_{3}$ 5\% ditandai dengan adanya perubahan warna menjadi hijau tua sedangkan dengan penambahan garam gelatin ditandai dengan adanya endapan putih (Kartikaningsih et al., 2019 \& Trisia et al., 2018).

Pada uji steroid dan triterpenoid pada penelitian ini menunjukkan hasil positif pada uji steroid dengan adanya perubahan warna menjadi biru. Hal ini sesuai dengan penelitian (Kartikaningsih et al., 2019), bahwa uji steroid akan mengalami perubahan warna menjadi biru sampai hijau. Hasil skrining menunjukkan negatif senyawa triterpenoid, dikarenakan tidak diperoleh perubahan warna merah jingga sampai ungu setelah penambahan asam sulfat pekat.

\section{Pengujian Aktivitas Antibakteri}

Penelitian ini merupakan pengujian aktivitas ekstrak etanol rumput laut cokelat (Sargassum cristaefolium) dengan konsentrasi 60\%, 80\% dan $100 \%$ terhadap isolat Staphylococcus epidermidis yang merupakan salah satu bakteri penyebab acne vulgaris. Penelitian ini dilakukan 
dengan tujuan untuk menentukan aktivitas antibakteri ekstrak etanol rumput laut cokelat (Sargassum cristaefolium) terhadap Staphylococcus epidermidis. Penelitian dilakukan secara in vitro dengan metode difusi sumuran menggunakan media nutrient agar (NA). Pemilihan media NA didasari karena merupakan media yang sudah teruji secara klinis baik untuk pertumbuhan bakteri dan telah dilakukan penelitian bahwa pada penggunaan media NA hasil koloni bakteri yang terbentuk terlihat lebih besar dan nyata serta mudah untuk diamati (Rahayu \& Anisah, 2015)

Parameter dalam pengujian ini yaitu dengan mengukur zona hambat (bagian bening) yang terbentuk disekitar sumuran. Metode ini dilakukan dengan menambahkan senyawa antimikroba ke dalam lubang sumuran yang dibuat dengan menggunakan Blue tip steril. Media NA terlebih dahulu di inokulasikan suspensi bakteri yang telah diremajakan dan telah disamakan kekeruhannya dengan standar MC Farland sebelum dilubangi (sumuran). Media yang telah ditambahkan konsentrasi ekstrak diinkubasi selama 24 jam dengan suhu $37^{\circ} \mathrm{C}$. setelah 24 jam dilakukan pengamatan dengan melihat zona hambat disekitar sumuran. Zona hambat yang terbentuk diukur menggunakan mistar. Gambar zona bening ekstrak etanol Sargassum cristaefolium diilustrasikan pada Gambar 2.

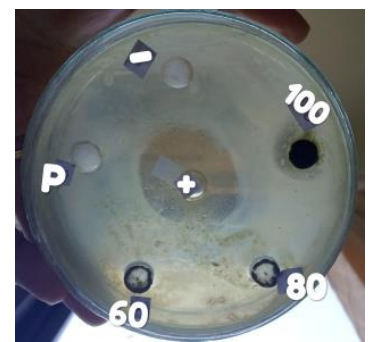

Gambar 2. Zona bening ekstrak etanol Sargassum cristaefolium

*Keterangan : P: Kontrol Pelarut; -; Kontrol Negatif; +: Kontrol Positif; 60: Konsentrasi Ekstrak 60\%; 80: Konsentrasi Ekstrak 80\%; I00: Konsentrasi Ekstrak 100\%

Hasil pengukuran uji aktivitas antibakteri ekstrak etanol Sargassum cristaefolium diilustrasikan pada tabel 2 .

Tabel 2. Hasil Pengukuran Uji Aktivitas Antibakteri Ekstrak Etanol Sargassum cristaefolium

\begin{tabular}{lccc}
\hline No. & Konsentrasi (\%) & Mean \pm SD & Kategori \\
\hline 1. & 60 & $1.96 \pm 0.71$ & Lemah \\
2. & 80 & $2.63 \pm 0.74$ & Lemah \\
3. & 100 & $9.46 \pm 1.60$ & Sedang \\
4. & Kontrol Positif & $20.17 \pm 1.03$ & Sangat kuat \\
5. & Kontrol Negatif & 0 & Tidak berefek \\
6. & Kontrol Pelarut & 0 & Tidak berefek \\
\hline
\end{tabular}

Dari hasil pengujian aktivitas antibakteri ekstrak etanol Sargassum cristaefolim terhadap Staphylococcus epidermidis pada tabel 2 menunjukkan adanya zona hambat yang terbentuk pada ketiga variasi konsentrasi. Diameter zona hambat yang terbentuk semakin meningkat seiring dengan peningkatan konsentrasi uji. Perbedaan rerata zona hambat dari setiap konsentrasi dapat disebabkan karena perbedaan kadar konsentrasi yang digunakan. Hal ini sesuai menurut penelitian Auliyah pada tahun 2016, semakin tinggi kadar konsentrasi ekstrak, maka semakin tinggi pula jumlah senyawa atau kandungan zat aktif di dalamnya yang bekerja untuk menghambat bakteri. Selain itu peningkatan konsentrasi ekstrak akan diikuti dengan peningkatan daya hambat pertumbuhan bakteri.

Pada gambar menunjukkan adanya zona bening pada kontrol positif yang artinya dapat menghambat pertumbuhan Staphylococcus epidermidis dengan katagori sangat kuat. Hal ini dikarenakan diameter zona hambat yang terbentuk > $20 \mathrm{~mm}$. Sedangkan bila dibandingkan dengan daya hambat konsentrasi ekstrak etanol Sargassum cristaefolium memiliki hasil yang lebih rendah. Dalam penelitian ini kontrol positif yang digunakan yaitu Doksisiklin 2\%. Doksisiklin merupakan golongan aminoglikosida yang bersifat bakteriostatis terhadap bakteri gram positif ataupun gram negatif. Doksisiklin bekerja dengan menghambat sintesis protein pada bakteri dan mengganggu subunit 30s ribosom. Sedangkan pada kontrol pelarut DMSO 10\% dan kontrol negative blanko tidak ditemukan zona hambat. Hal ini dikarenakan pelarut DMSO $10 \%$ tidak menghambat pertumbuhan bakteri bila digunakan dibawah I5\% (Sharma \& Sharma, 20II)

Terjadinya proses penghambatan pertumbuhan dari Staphylococcus epidermidis yang terlihat pada gambar 2 dapat disebabkan karena adanya aktivitas antibakteri dari senyawa flavonoid, tanin, saponin, alkaloid, dan steroid yang terkandung dalam ekstrak etanol Sargassum cristaefolium. Hal ini sesuai dengan penelitian (Madduluri et al., 2013), bahwa kandungan fitokimia seperti alkaloid, flavonoid, tanin, 
saponin, steroid, dan beberapa senyawa aromatik lainnya berfungsi sebagai pertahanan terhadap mikroorganisme dan bertanggung jawab sebagai antimikroba. Senyawa-senyawa tersebut memiliki aktivitas sebagai antibakteri dengan mekanisme kerja merusak membran sel bakteri, menyebabkan kebocoran sel dan bekerja dengan mendenaturasi protein bakteri serta meningkatkan permeabilitas sel.

Data yang berupa zona hambat yang diperoleh selanjutnya di analisis menggunakan uji One Way ANOVA. Berdasarkan hasil uji Anova One Way menunjukkan nilai sig $=.000$ atau nilai $\mathrm{p}<0.05$ yang berarti setiap kelompok uji memiliki perbedaan bermakna, yang juga bermakna bahwa setiap kelompok uji memiliki aktivitas antibakteri yang berbeda-beda.

\section{Simpulan}

Berdasarkan hasil penelitian uji aktivitas antibakteri Staphylococcus epidermidis menggunakan ekstrak etanol Sargassum cristaefolium ini dapat disimpulkan bahwa ekstrak etanol Sargassum cristaefolium konsentrasi I00\% memiliki efek sebagai antibakteri dalam menghambat pertumbuhan Staphylococcus epidermidis dengan daya hambat $9.46 \pm 1.60$ yang termasuk katagori sedang, sedangkan pada konsentrasi $80 \%$ dan 60\% diperoleh daya hambat $2.63 \pm 0.74$ dan $1.96 \pm$ 0.7I dengan katagori lemah.

\section{Ucapan Terima Kasih}

Penulis mengucapkan terima kasih kepada pihak Laboratorium Bioscience dan Bioteknologi Universitas Mataram (PUBB) yang telah membantu dalam pengambilan sampel rumput laut yang digunakan di dalam penelitian ini, dan pihak Laboratorium Penelitian Program Studi Farmasi Universitas Mataram serta semua pihak lainnya yang telah membantu dalam menyelesaikan penelitian ini.

\section{Daftar Pustaka}

Anisah, \& Rahayu, T. (20I5). Media Alternatif untuk Pertumbuhan Bakteri Menggunakan Sumber Karbohidrat yang Berbeda Alternative Media FOR Bacterial Growth Using a different Source of Carbohidrats, Proceeding, Seminar Nasional XII Pendidikan Biologi FKIP UNS Surakarta, 855-860.

Annisa, R. D., Subandiyono., dan Sudaryono, A. (2018). Pengaruh Tepung Alga Coklat (Sargassum cristaefolium) dalam Pakan Buatan terhadap Efisiensi Pemanfaatan Pakan dan Pertumbuhan Ikan Kerapu (Epinephelus fuscoguttatus), Jurnal Sains Teknologi Akuakultur,2(I),35-42

http://jsta.aquasiana.org/index.php/jmai/arti cle/view/33

Bernadette, I., Sitohang, S., Fathan, H., Effendi, E., \& Wahid, M. (2019). The susceptibility of pathogens associated with acne vulgaris to antibiotics. 2I-27.

Chomnawang, M. T., Surassmo, S., Nukoolkarn, V. S., \& Gritsanapan, W. (2007). Effect of Garcinia mangostana on inflammation caused by Propionibacterium acnes. Fitoterapia, 78(6), 40I-408. https://doi.org/I0.1016/j.fitote.2007.02.01 9

Desrizal, Karina, I., \& Mardiah, A.(2020). Microbiological Quality of Brown Seaweed (Sargassum sp.) Dodol Packed with Carrageenan and Chitosan Coatings, Pakistan Journal Of Nutrition, I9(6), 309-I6. https://doi.org/I0.3923/pjn.2020.309.3I6

Fitri, I., \& Widiyawati, D. I. (2017). Efektivitas Antibakteri Ekstrak Herba Meniran ( Phylanthus niruni) Terhadap Pertumbuhan Bakteri Salmonella Sp . dan Propionibacterium acnes. 6(2).

Freire, J. F. S., Vilar, G. N., dan Filho, S. (2015). Quality Of Life, Self-Esteem And Psychosocial Factors In Adolescents With Acne Vulgaris, Anais Brasileiros Dermatolgia, 90(5), 622-9.

Garrett, J. P., \& Margolis, D. J. (2012). Impact of Long-Term Antibiotic Use for Acne on Bacterial Ecology and Health Outcomes: A Review of Observational Studies. 23-28. https://doi.org/I0.1007/sI367I-0I I-000I7

Guay, D. R. P. (2007). Topical clindamycin in the management of acne vulgaris. Expert Opinion on Pharmacotherapy, 8(I5), 2625-2664. https://doi.org/I0.I5I7/I4656566.8.15.26 25

Hartono, L. M., Kapantow, M. G., \& Kairupan, T. S. (202I). Pengaruh Menstruasi terhadap Akne Vulgaris. 9(28), 305-3I0.

Kartikaningsih, H., Yahya, Dayuti, S., Tumulyadi, A., \& Umam, R. S. (2019). Characteristics brown seaweed tea Sargassum cristaefolium from Talango Island, Madura, East Java. AIP Conference Proceedings, 2I20(July). https://doi.org/I0.I063/I.5I I5620

Kumesan, Y. A. N., Yamlean, P. V. Y., Supriati, H. S., Studi, P., \& Unsrat, F. (2013). Formulasi Dan Uji Aktivitas Gel Antijerawat Ekstrak Umbi Bakung ( Crinum Asiaticum L .) Terhadap Bakteri Staphylococcus aureus Secara In Vitro. 2(02), 18-27.

Kursia, S., Lebang, J. S., Taebe, B., Burhan, A., Rahim, W. O. ., \& Nursamsiar. (2016). Uji Aktivitas Antibakteri Ekstrak Etilasetat Daun Sirih Hijau (Piper betle L.) terhadap Bakteri Staphylococcus epidermidis. Indonesian 
Journal of Pharmaceutical Science and Technology, 3(2), 72-77.

Kusnadi, K., \& Devi, E.T, (2017), Isolasi Dan Identifikasi Senyawa Falvoniid Pada Ekstrak Daun Seledri (Apium grveolens L.) Dengan Metode Refluks, Pancasakti Science Education Journal, 2(I), 56-67.

Latifah, S., \& Kurniawaty, E, (2015), Stres dengan Akne Vulgaris Stress in Acne Vulgaris. Medical Journal Of Lampung University ,4(9), 129I34.

Madduluri, S., Babu Rao, K., \& Sitaram, B. (2013). In Vitro Evaluation Of Antibacterial Activity Of Five Indigenous Plants Extract Against Five Bacterial Pathogens Of Human. International Journal of Pharmacy and Pharmaceutical Sciences, 5(4), 679-684.

Made, N., Rakasari, G., Duniaji, A. S., Nocianitri, K. A., Pertanian, F. T., Pertanian, F. T., \& Jimbaran, K. B. (2019). Kandungan Senyawa Flavonoid Dan Antosianin Ekstrak Kayu Secang ( Caesalpinia Sappan L .) Serta Aktivitas Antibakteri Terhadap Vibrio cholerae. 8(2), 216-225.

Manggau, M., Damayanty, R., \& M, L. (2017). Uji Efektivitas Kelembaban Sabun Transparan Ekstrak Rumput Laut Cokelat ( Sargassum Cristaefolium C. Agardh) dengan Variasi Konsentrasi Sukrosa. Journal of Pharmaceutical and Medicinal Sciences, 2(I), 2I-26.

Minarti, S., Idiawati, N., Sari, M., \& Sofiana, J. (2019). polycystum dari perairan Pulau Lemukutan Kalimantan Barat. 2(I), 60-65.

Rosmania., \& Yanti, F. (2020), Perhitungan jumlah bakteri di Laboratorium Mikrobiologi menggunakan pengembangan metode Spektrofotometri, Jurnal Penelitian Sains, 22(2), 76-86.

Sawarkar, H. A., Khadabadi, S. S., Mankar, D. M., Farooqui, I. A., \& Jagtap, N. S. (2010). Development and Biological Evaluation of Herbal Anti-Acne Gel. 2(3), 2028-203I.

Sharma, A., \& Sharma, K. (20II). Should Solubility and Zone of Inhibition Be the Only Criteria for Selection of Solvent in Antimicrobial Assay? 5(5), 24I-247.

Simaremare, E.S. (20I4). Skrining Fitokimia Ekstrak Etanol Daun Gatal (Laportea decumana (Roxb.) Wedd). Pharmacy, II (I) , 98-I07.

Syafriana, V., Febriani, A., Suyatno., Nurfitri., \& Hamida, F. (202I), Antimicrobial Activity of Ethanolic Extract of Sempur (Dillenia suffruticosa (Griff.) Martelli) Leaves against Pathogenic Microorganisms, Borneo Journal of Pharmacy, 4(2), I35-I44

Triastrinurmiatiningsih, Ismanto, \& Ertina. (2011). Variasi Morfologi Dan Anatomi Sargassum spp. Di Pantai Bayah Banten. Ekologia, II(2), I-IO.

Trisia, A., Philyria, R., \& Toemon, A. N. (20I8). Uji Aktivitas Antibakteri Ekstrak Etanol Daun
Kalanduyung ( Guazuma Ulmifolia Lam .) Terhadap Pertumbuhan Staphylococcus aureus Dengan Metode Difusi Cakram ( Kirby-Bauer ), I7(2), I36-I43.

Wibawa, I. G. A. E., \& Winaya, K. K. (2019). Karakteristik penderita acne vulgaris di Rumah Sakit Umum (RSU) Indera Denpasar periode 20I4-2015. Jurnal Medika Udayana, 8( I I), I4. https://ojs.unud.ac.id

Winastri, N. L. A. P., Muliasari, H., dan Hidayati, E. (2020). Aktivitas Antibakteri Air Perasan dan Rebusan Daun Calincung (Oxalis corniculata L.) Terhadap Streptococcus mutans, Lembaga Ilmu Pengetahuan Indonesia, I9(I), 223-30. 